\title{
Effects on global CO2 emissions when substituting LPG with bio-SNG as fuel in steel industry reheating furnaces: The impact of different perspectives on $\mathrm{CO} 2$ assessment
}

\author{
Maria Johansson
}

\section{Linköping University Post Print}

\section{Tweet}

N.B.: When citing this work, cite the original article.

The original publication is available at www.springerlink.com:

Maria Johansson, Effects on global CO2 emissions when substituting LPG with bio-SNG as fuel in steel industry reheating furnaces: The impact of different perspectives on $\mathrm{CO} 2$ assessment, 2016, Energy Efficiency.

http://dx.doi.org/10.1007/s12053-016-9432-0

Copyright: Springer Verlag (Germany)

http://www.springerlink.com/?MUD=MP

Postprint available at: Linköping University Electronic Press

http://urn.kb.se/resolve?urn=urn:nbn:se:liu:diva-125377 


\title{
Effects on global $\mathrm{CO}_{2}$ emissions when substituting LPG with Bio-SNG as fuel in steel industry reheating furnaces - the impact of different perspectives on $\mathrm{CO}_{2}$ assessment
}

\author{
Maria T. Johansson \\ Department of Management and Engineering, Division of Energy Systems, \\ Linköping University, SE-581 83 Linköping, Sweden \\ E-mail address: maria.johansson@liu.se
}

\begin{abstract}
The iron and steel industry is the second largest user of energy in the world industrial sector and is currently highly dependent on fossil fuels and electricity. Substituting fossil fuels with renewable energy in the iron and steel industry would make an important contribution to the efforts to reduce emissions of $\mathrm{CO}_{2}$. However, different approaches to assessing $\mathrm{CO}_{2}$ emissions from biomass and electricity use generate different results when evaluating how fuel substitution would affect global $\mathrm{CO}_{2}$ emissions. This study analyses the effects on global $\mathrm{CO}_{2}$ emissions when substituting liquefied petroleum gas with synthetic natural gas, produced through gasification of wood fuel, as a fuel in reheating furnaces at a scrap-based steel plant. The study shows that the choice of system perspective has a large impact on the results. When wood fuel is considered available for all potential users, a fuel switch would result in reduced global $\mathrm{CO}_{2}$ emissions. However, applying a perspective where wood fuel is seen as a limited resource and alternative use of wood fuel is considered, a fuel switch could in some cases result in increased global $\mathrm{CO}_{2}$ emissions. As an example, in one of the scenarios studied, a fuel switch would reduce global $\mathrm{CO}_{2}$ emissions by $52 \mathrm{ktonnes/year} \mathrm{if} \mathrm{wood} \mathrm{fuel} \mathrm{is} \mathrm{considered}$ available for all potential users, while seeing wood fuel as a limited resource implies, in the same scenario, increased $\mathrm{CO}_{2}$ emissions by 70 ktonnes/year. The choice of method for assessing electricity use also affects the results.
\end{abstract}

Keywords: Iron and steel industry; Fuel switch; Biomass; $\mathrm{CO}_{2}$ emissions assessment; Energy market scenarios

\section{Introduction}

The iron and steel industry is the second largest user of energy in the world industrial sector and accounts for approximately $6 \%$ of total global $\mathrm{CO}_{2}$ emissions (IEA 2013a). The iron and steel industry is energy-intensive and relies to a great extent on fossil fuels and electricity. There are two main routes for steel production: iron ore-based steel production and scrapbased steel production. The most common iron ore-based steel production is the blast furnace-basic oxygen furnace route (BF-BOF); blast furnace iron represented $94 \%$ of global iron production in 2013 (World Steel Association 2014). In the BF-BOF route, $95 \%$ of the 
energy input is coke and coal to blast furnace and coke ovens, $3 \%$ is electricity and the rest is chemical energy in scrap (Lindeström et al. 2008). In contrast, energy input to the scrap-based steel production in electric arc furnaces consists of $80 \%$ electricity and the rest is fossil fuels (Åbyhammar and Östergård 2001). In a scrap-based steel plant, the fossil fuels are used in reheating furnaces and for steam production.

The steel industry's high fossil fuel dependency is problematic from a climate change perspective. Moreover, it concerns the individual steel companies with regard to security of energy supply and economy. Locally available renewable energy could offer a secure supply of energy. Furthermore, reduced use of fossil fuels would imply lower $\mathrm{CO}_{2}$ emissions charges for the industry. Policy measures that aim towards reduced greenhouse gas emissions (e.g. EU-ETS) and increased use of renewable energy (e.g. the EU renewable energy directive) affect the iron and steel industry, and there are extensive investments in finding alternative steelmaking processes with lower $\mathrm{CO}_{2}$ emissions (ULCOS 2015; AISI 2015; JISF 2011; POSCO 2015). The possibility of substituting the steel industry's fossil fuels with biomass is an interesting option. However, large quantities would be needed and the demand for biomass would at the same time increase in other sectors such as the energy and transport sector. This study highlights the consequences of increased demand for wood fuel in the future and the fact that the resource does not have the capacity to be a substitute for fossil fuels in all sectors. It is therefore important to evaluate where the resource should be used in order to achieve the largest $\mathrm{CO}_{2}$ mitigation effect.

However, different approaches to assessing $\mathrm{CO}_{2}$ emissions from biomass and electricity use could affect the results when evaluating how fuel substitution would affect global $\mathrm{CO}_{2}$ emissions. This study analyses the effects on global $\mathrm{CO}_{2}$ emissions when substituting liquefied petroleum gas (LPG) with synthetic natural gas (SNG), produced through gasification of wood fuel, as fuel in reheating furnaces at a Swedish scrap-based steel plant. Different perspectives on assessing $\mathrm{CO}_{2}$ emissions from biomass and electricity use are compared.

\section{$\mathrm{CO}_{2}$ assessment of electricity and biomass use}

There are different approaches for assessing $\mathrm{CO}_{2}$ emissions from electricity production and electricity use. One approach is the average electricity mix. In this case, $\mathrm{CO}_{2}$ emissions are calculated for the average mix of fuels used in electricity production in the geographical area studied (Dotzauer 2010; Levihn 2014). This approach is based on the view that changes in electricity demand and production affect all production technologies in the system equally. Power production in Sweden is based on nuclear (38 \%) and hydropower (48 \%), and results in low emissions of $\mathrm{CO}_{2}$ (Swedish Energy Agency 2014). However, Sweden's electricity system is interconnected with the Nordic system and the Nordic countries trade electricity on the power market Nord Pool Spot. Therefore, when analysing $\mathrm{CO}_{2}$ emissions from electricity use in Sweden, Nordic electricity mix would be more accurate than Swedish electricity mix. Electricity can also be exported or imported to and from other European countries through Nord Pool Spot, which suggests that a European perspective should be applied, especially for future studies when the transmission capacity between the European countries would not be a 
bottleneck. The average electricity mix method is commonly used for accounting purposes when the electricity supply and demand are known (Dotzauer 2010).

However, when studying changes in electricity production and demand, the average electricity mix would not reflect the real consequences. The average electricity mix is more appropriate for evaluating already used electricity, and not for evaluating measures that affect future use of electricity. Therefore, it is argued that marginal electricity production should be applied when analysing the impact of changed production or consumption (Dotzauer 2010; Levihn 2014; Hawkes 2014, 2010). According to this consequential perspective, changes in electricity production in a short time perspective (a few years) would affect the technologies with the highest operational cost at a given time. This is referred to as operating-margin electricity. The operating-margin perspective could be applied in different ways, e.g. it is possible to use emissions factors for the technology for which production is considered most likely to be affected by demand changes (Dotzauer 2010), or to calculate margin emissions factors based on operational data on how technologies respond to load changes (Hawkes 2014, 2010). However, long-term changes (decades) in energy systems affect not only the electricity on the operating margin but also the construction of new power units. This is called build-margin electricity and corresponds to the electricity production facility that will be built when new capacity is needed (Broekhoff et al. 2007). It could also be generation capacity that is not installed due to reduced electricity demand. It is recommended that this perspective is applied when studying strategic or long-term changes to the energy system (Axelsson et al. 2009).

Traditionally, the use of biomass is considered $\mathrm{CO}_{2}$ neutral as long as harvesting is sustainable and accompanied by replanting. Applying a life cycle assessment (LCA) to this perspective, biomass use contributes only to climate change through activities like felling and transportation and not through the actual energy utilisation. In this case, utilising biomass in one energy system would not affect the composition of fuels in other energy systems. This view of biomass could be appropriate for short-term studies, where the resource is available for all potential users. However, biomass is a limited resource and there would be both local and international competition for the resource in the future. Therefore, an analysis of future changes in biomass use should include alternative use of biomass. The user that would use less or no biomass as a result of the competition is the marginal (price-setting) biomass user. This perspective suggests that the increase in $\mathrm{CO}_{2}$ emissions originating from the additional use of fossil fuels by the marginal biomass user, as a result of this competition, should be allocated to the new user of biomass.

\section{System studied}

The steel plant in this study is situated in Sweden and produces steel from scrap in an electric arc furnace with a charge weight of 75 tonnes. The steel plant has a large production capacity and produces tubes, wires and strips in advanced steel materials. Each year approximately $220 \mathrm{GWh}$ of liquefied petroleum gas (LPG) is used as fuel in reheating furnaces at the steel plant. After some modifications of the furnaces and the gas distribution system, this fossil fuel could be substituted with synthetic natural gas (SNG) produced from biomass. 
Bio-SNG can be produced from biomass through a process called gasification. This is a thermochemical process which converts the carbonaceous feedstock into a product gas, syngas, consisting mainly of $\mathrm{CO}$ and $\mathrm{H}_{2}$. The syngas can be converted to a number of products, such as SNG. Gasification of fossil coal has been used commercially for decades, but gasification of biomass is currently at the development stage. In this study, the bio-SNG is produced from wood fuel in a pressurised, oxygen-blown, circulating fluidised bed gasifier with a gas cleaning system comprising a high temperature filter and catalytic tar reforming technology. The gasifier is followed by a methanation reactor where the syngas is converted to SNG. The studied system can be seen in Figure 1.

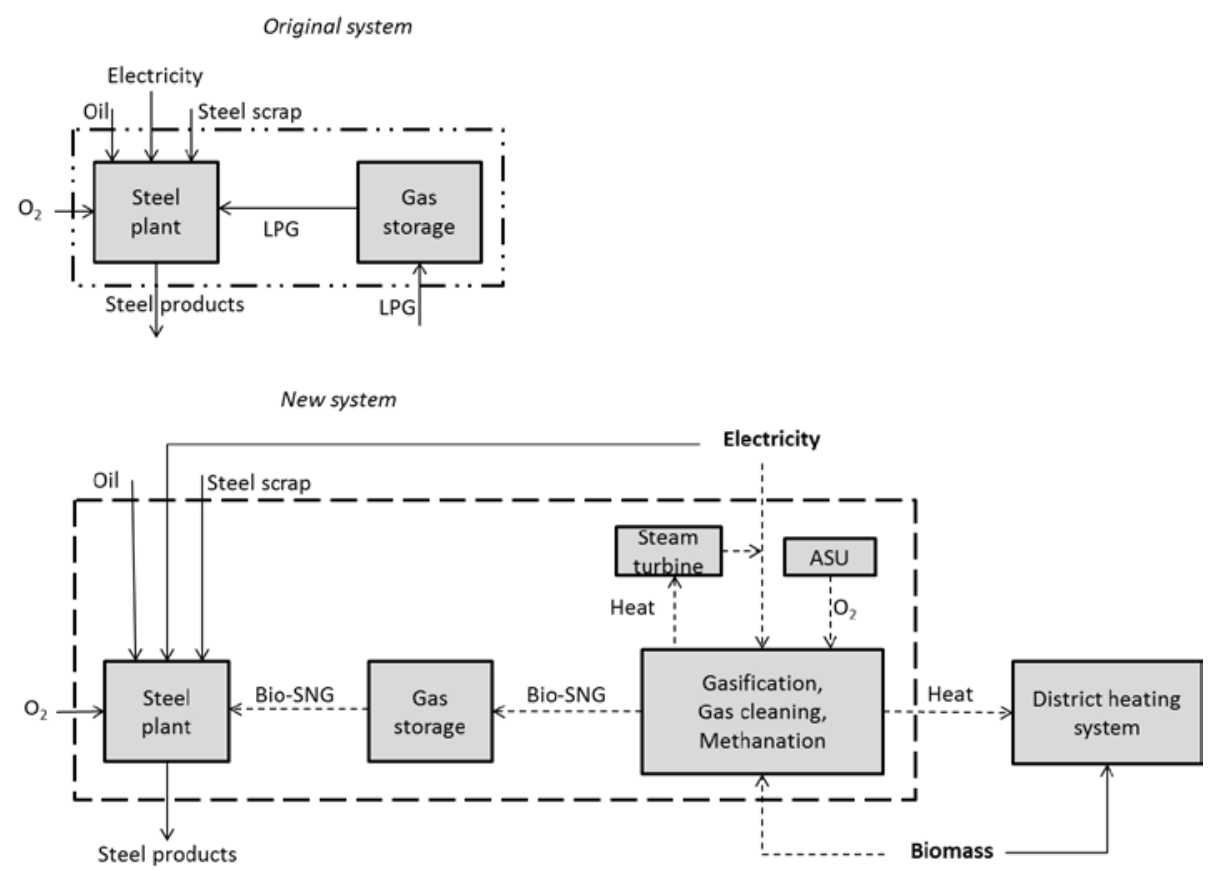

Figure 1. The system studied. The original system is shown at the top and the new system at the bottom. Dotted arrows show the new energy flows introduced when a biomass gasification and methanation system produces fuel for the steel plant. The gasifier's oxygen demand is supplied by an air separation unit (ASU) and electricity is produced from heat from the gas cooling system.

The data for the gasification and methanation system was taken from a study (Chalmers Energy Centre 2007) preceding the construction of the gasification facility GoBiGas in Gothenburg. GoBiGas was brought into operation in 2014 (Göteborg Energi 2016). The gasification technology is the same as that used in the gasifier in Güssing, Austria, which has been in operation since 2002 (EEE 2016). Fluidized bed gasification is an excellent method for the gasification of biomass, since the design is rather insensitive to fuel quality and results in good mixing and uniform temperature (Basu 2010). Fluidized bed gasification is appropriate for intermediate units (5 $\left.\mathrm{MW}_{\mathrm{th}}-100 \mathrm{MW}_{\mathrm{th}}\right)$.

Table 1 presents performance data for the gasification system. It was assumed that the gasifier operates $8000 \mathrm{~h} /$ year and that excess heat from the gasification system could be delivered to a district heating $(\mathrm{DH})$ system during all production hours. Steam from the gas cooling system is used to produce electricity in a steam turbine. 
Table 1. Performance data for the gasification and methanation system analysed. The capacity of the gasification system is $45 \mathrm{MW}_{\text {th }}$ and it operates at $43 \mathrm{MW}_{\text {thr }}$. The system includes a circulating fluidized bed gasifier, a gas cleaning system, a methanation reactor, an air separation unit (ASU) and a steam turbine. Data was based on (Chalmers Energy Centre 2007).

\begin{tabular}{|c|c|c|c|c|c|c|}
\hline Biomass input & SNG output & Electricity $\left(\mathrm{MW}_{\mathrm{e}}\right)$ & & DH production & Efficiency & \\
\hline$\left(\mathrm{MW}_{\mathrm{th}}\right)$ & $\left(\mathrm{MW}_{\text {bio-SNG }}\right)$ & & & $\left(\mathrm{MW}_{\text {heat }}\right)$ & & \\
\hline \multirow[t]{3}{*}{43} & 27.6 & Demand: & 3.2 & 10.2 & SNG: & 0.64 \\
\hline & & Production: & 2.4 & & Electricity: & -0.02 \\
\hline & & Net production: & -0.8 & & DH: & 0.24 \\
\hline
\end{tabular}

\section{Methods}

The consequences of substituting LPG with bio-SNG were calculated according to Equation 1 $\Delta \mathrm{CO}_{2}=\mathrm{CO}_{2}$ new system $-\mathrm{CO}_{2}$ original system

(Equation 1)

Global $\mathrm{CO}_{2}$ emissions from electricity use were assessed from three perspectives: (1) Swedish average electricity mix, (2) European average electricity mix, and (3) build-margin technology for electricity production. The time frame of the analysis for the build-margin perspective was 2030, and fully deregulated markets for electricity and wood fuel were assumed. Build-margin technology for electricity production was assumed to be coal condensing power (CCP) plants or natural gas combined cycle (NGCC) plants. The emissions factor used for the Swedish electricity mix was $43 \mathrm{~kg} \mathrm{CO} / \mathrm{MWh}_{\mathrm{e}}$, and $396 \mathrm{~kg} \mathrm{CO} / \mathrm{MWh}_{\mathrm{e}}$ was used for the European electricity mix (European Environment Agency 2009). These factors may of course be lower in 2030 compared with today's values, but the exact values are not critical in this study as the purpose is to exemplify different perspectives on $\mathrm{CO}_{2}$ assessments and not to show accurate forecasts.

Biomass was limited to low and high grade wood fuel, e.g. forestry logging residues and wood pellets. Global $\mathrm{CO}_{2}$ emissions from wood fuel use were assessed from two perspectives: (1) wood fuel is available for all potential users and (2) wood fuel is a limited resource on the market and the increase in $\mathrm{CO}_{2}$ emissions originating from additional use of fossil fuel by the marginal biomass user is allocated to the new user of biomass. For the perspective of biomass as a limited resource, two technologies were assumed to be potential marginal users of wood fuel: coal condensing power plants with wood fuel co-firing and producers of biofuels to the transport sector, in this case Fischer Tropsch (FT) diesel (Axelsson and Harvey 2010).

The market for DH would be determined by local conditions and two types of Swedish DH systems were considered: a small system ${ }^{1}$ in which the majority of the heat is produced in

\footnotetext{
${ }^{1}$ Composition of heat production: 86 \% bio-HOB, 4 \% coal-HOB, 2 \% natural gas-HOB, 4 \% oil-HOB, $4 \%$ other renewables.
} 
bio-fuelled heat-only boilers (bio-HOB) and a large system ${ }^{2}$ in which most of the heat is produced in bio-fuelled combined heat and power (CHP) plants.

Consistent energy market scenarios (EMS) for the analysis were generated by the Energy Price and Carbon Balance (ENPAC) tool, and the output from the tool was $\mathrm{CO}_{2}$ emissions factors for fossil fuels, wood fuel, electricity and heat (see Table 2).

Table 2. $\mathrm{CO}_{2}$ emissions factors generated by the ENPAC tool when considering LCA and build-margin electricity. Two perspectives on wood fuel are shown: (1) wood fuel is considered available for all potential users or (2) alternative use of wood fuel is considered. Input to the ENPAC tool was fossil fuel prices and $\mathrm{CO}_{2}$ emissions charges taken from World Energy Outlook (WEO) 2013, which represent the new policies scenario (input to EMS-1) and the 450 ppm scenario (input to EMS-2) (IEA 2013b). In addition, average values of the prices from the scenarios in WEO 2013 were input into a third energy market scenario (EMS-3).

\begin{tabular}{|c|c|c|c|}
\hline Energy market scenario (EMS) & EMS-1 & EMS-2 & EMS-3 \\
\hline Build-margin technology for electricity & $C C P^{a}$ & $N G C C^{b}$ & CCP \\
\hline Marginal user of wood fuel ${ }^{c}$ & $F T^{d}$ & $C C P$ & CCP \\
\hline \multicolumn{4}{|l|}{ Biomass as unlimited resource } \\
\hline LPG $\left(\mathrm{kg} \mathrm{CO}_{2} / \mathrm{MWh}_{\text {fuel }}\right)$ & 245 & 245 & 245 \\
\hline Natural gas $\left(\mathrm{kg} \mathrm{CO}_{2} / \mathrm{MWh}_{\text {fuel }}\right)$ & 224 & 224 & 224 \\
\hline Biomass $\left(\mathrm{kg} \mathrm{CO}_{2} / \mathrm{MWh}_{\text {fuel }}\right)$ & 8 & 8 & 8 \\
\hline Electricity $\left(\mathrm{kg} \mathrm{CO}_{2} / \mathrm{MWh}_{\mathrm{e}}\right)$ & 714 & 340 & 714 \\
\hline \multicolumn{4}{|l|}{ District heating $\left(\mathrm{kg} \mathrm{CO}_{2} / \mathrm{MWh}_{\text {heat }}\right)$} \\
\hline Bio-HOB ${ }^{\mathrm{e}}$ in Sweden & 43 & 43 & 43 \\
\hline Bio-CHP ${ }^{f}$ in Sweden & -148 & -33 & -148 \\
\hline \multicolumn{4}{|l|}{ Biomass as limited resource } \\
\hline LPG $\left(\mathrm{kg} \mathrm{CO} / \mathrm{MWh}_{\text {fuel }}\right)$ & 245 & 245 & 245 \\
\hline Natural gas $\left(\mathrm{kg} \mathrm{CO}_{2} / \mathrm{MWh}_{\text {fuel }}\right)$ & 224 & 224 & 224 \\
\hline Biomass ( $\mathrm{kg} \mathrm{CO} / \mathrm{MWh}_{\text {fuel }}$ ) & 119 & 356 & 356 \\
\hline Electricity $\left(\mathrm{kg} \mathrm{CO}_{2} / \mathrm{MWh}_{\mathrm{e}}\right)$ & 714 & 340 & 714 \\
\hline \multicolumn{4}{|l|}{ District heating $\left(\mathrm{kg} \mathrm{CO}_{2} / \mathrm{MWh}_{\text {heat }}\right)$} \\
\hline Bio-HOB ${ }^{\mathrm{e}}$ in Sweden & 150 & 363 & 363 \\
\hline Bio-CHP ${ }^{\mathrm{f}}$ in Sweden & -19 & 351 & 236 \\
\hline
\end{tabular}

${ }^{a}$ Coal condensing power plant, ${ }^{b}$ Natural gas combined cycle, ${ }^{c}$ For the scenarios with limited biomass availability, ${ }^{\mathrm{d}}$ Producer of Fischer Tropsch diesel, ${ }^{\mathrm{e}}$ Heat-only-boiler, ${ }^{\mathrm{f}}$ Combined heat and power

\footnotetext{
${ }^{2}$ Composition of heat production: 55 \% bio-CHP, 3 \% coal-CHP, $28 \%$ bio-HOB, 4 \% heat pumps, $6 \%$ natural gas-CHP, $1 \%$ coalHOB, $1 \%$ natural gas-HOB, $1 \%$ oil-HOB, $1 \%$ other renewables.
} 
The emissions factors are the life cycle emissions and include the whole production chain. The ENPAC tool was developed at Chalmers University of Technology, and a thorough description of the tool can be found in Axelsson and Harvey (2010) and Axelsson et al. (2009). The input to the tool was fossil fuel prices on the commodity market and $\mathrm{CO}_{2}$ emissions charges for 2030 taken from scenarios developed by IEA (2013b). The scenarios were the new policies (np) scenario (input to EMS-1) and the $450 \mathrm{ppm}$ scenario (input to EMS-2). The np scenario assumes that recent policy commitments made up to 2013 are supposed to be implemented, whereas the $450 \mathrm{ppm}$ scenario is based on a global energy pathway with a $50 \%$ chance of meeting the goal of limiting the increase in global mean temperature to $2^{\circ} \mathrm{C}$ above the pre-industrial level. In addition, average values of the prices from these WEO-scenarios were input into a third EMS (EMS-3).

\section{Results and discussion}

It is challenging to predict the future energy market and how changes in energy systems, e.g. a fuel switch, would affect emissions of $\mathrm{CO}_{2}$. Therefore, different consistent energy market scenarios should be used in order to obtain a more thorough analysis of energy-related investments. This study analyses the effects on global $\mathrm{CO}_{2}$ emissions in the event of a fuel switch from a fossil fuel to a biomass-based fuel at a steel plant. It is shown that the choice of perspective on biomass availability greatly affects the outcome of the analysis. In Figure 2, it can be seen that when wood fuel is considered available for all potential users (unlimited resource) a fuel switch at the steel plant would result in reduced global $\mathrm{CO}_{2}$ emissions in all EMSs studied. However, applying a long-term perspective where competition of wood fuel is included and alternative use is considered (limited resource), a fuel switch could in some cases result in increased global $\mathrm{CO}_{2}$ emissions. This would be the case if the steel plant's fuel switch results in a CCP plant reducing its purchase of wood fuel and hence substituting less fossil coal with wood fuel in the production of electricity (EMS-2 and EMS-3) (see Figure 2). Hence, substituting fossil coal in the CCP plant with wood fuel would reduce $\mathrm{CO}_{2}$ emissions more than substituting LPG at the steel plant. However, it would be more advantageous from a $\mathrm{CO}_{2}$ emissions perspective to use bio-SNG as fuel in steel industry reheating furnaces than to produce biofuel for the transport sector (EMS-1). This is due to the assumption that wood fuel could be burnt directly in the CCP plant substituting an equal amount of fossil coal, while in the case of biofuels the wood fuel has to be converted to FT diesel (with a conversion factor of 0.4 ) before the FT diesel could replace fossil diesel in the transport sector, or converted to bio-SNG (with a conversion factor of 0.64) before replacing LPG at the steel plant. Moreover, fossil coal has a $\mathrm{CO}_{2}$ emissions factor of $364 \mathrm{~kg} / \mathrm{MWh}$, while the emissions factors for fossil diesel and LPG are $284 \mathrm{~kg} / \mathrm{MWh}$ and $245 \mathrm{~kg} / \mathrm{MWh}$ respectively (Gode et al. 2011). This is in line with results presented by Gustavsson et al. (2015), who stated that bioenergy as a substitute for fossil coal has a larger climate change benefit than replacing fossil diesel with bioenergy as transportation fuel. Hence, including the effects of allocating $\mathrm{CO}_{2}$ emissions from alternative use of wood fuel has a great impact on the results when CCP plants are the marginal users (see EMS-2 and EMS-3 in Figure 2). 


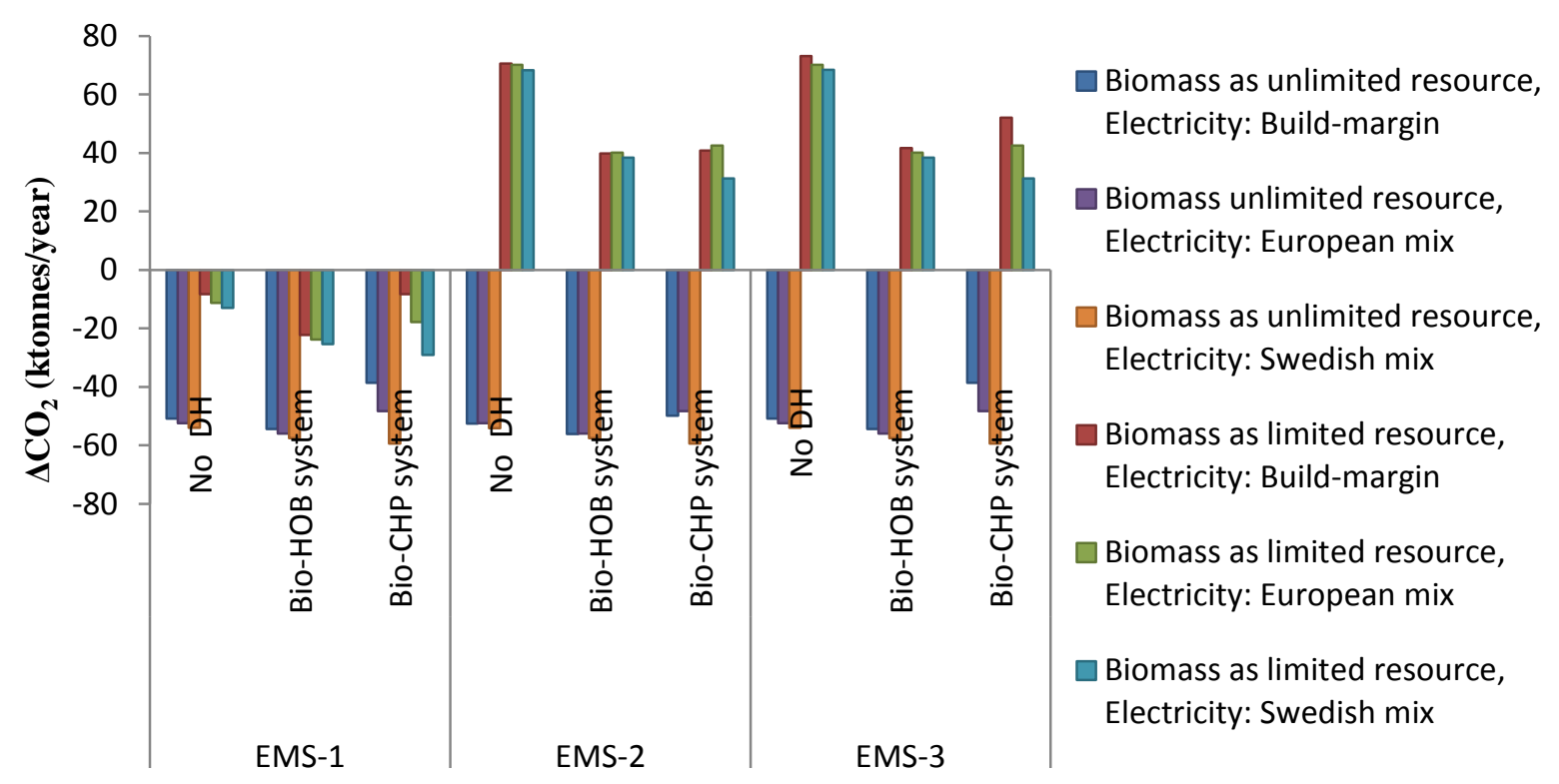

Figure 2. Effects on global CO2 emissions if a scrap-based steel plant in Sweden substitutes 220 GWh LPG per year with bio-SNG as fuel in reheating furnaces. Negative values correspond to reduced emissions.

Which method is applied for assessing electricity use also affects the results, because the new system with production of bio-SNG has a larger electricity demand than the original system with the steel plant using LPG as fuel. In EMS-2, build-margin technology for electricity is NGCC with a $\mathrm{CO}_{2}$ emissions factor similar to the European electricity mix, which means that in this EMS the difference between these electricity assessment approaches is small. The largest differences between the electricity assessment perspectives can be seen when coalgenerated power is assumed to be the build-margin technology supplying the increased electricity demand (EMS-1 and 3). This is in line with results presented by Cherubini (2010), who stated that a high $\mathrm{CO}_{2}$ emissions reduction could be achieved when coal-generated power is displaced with electricity generated from bioenergy, while a lower degree of savings would be achieved when displacing power from natural gas.

The choice of perspectives on biomass and electricity use also affects the results of how excess heat recovery and export of the heat to a $\mathrm{DH}$ system would affect global $\mathrm{CO}_{2}$ emissions (see Figure 2). When the DH system is a small Swedish system (bio-HOB system), excess heat delivery to the $\mathrm{DH}$ system would reduce global $\mathrm{CO}_{2}$ emissions in all cases studied. However, when excess heat replaces heat production in a large Swedish DH system (bio-CHP system) and biomass is considered available for all potential users, emissions would increase in all scenarios assuming build-margin electricity or the European average electricity mix. This can be explained by the fact that the bio-CHP co-produces heat and electricity, and when the demand for heat production is reduced, electricity production is also reduced. The reduced electricity production has to be compensated for with other electricity production. The reduced $\mathrm{CO}_{2}$ emissions, as a result of reduced fuel consumption in the $\mathrm{DH}$ system, could - in the cases of build-margin electricity and the European electricity mix - not compensate for the increased $\mathrm{CO}_{2}$ emissions from higher fossil fuel demand in the electricity system. The Swedish electricity mix has a low emissions factor, which explains why excess heat delivery would always be advantageous from a $\mathrm{CO}_{2}$ emissions perspective when assuming that the Swedish electricity mix compensates for the reduced electricity production in bio-CHP plants. 
Considering alternative use of wood fuel (biomass limited resource), excess heat delivery to a bio-based DH system would reduce the demand for wood fuel in the DH system, making it available for other users. With regard to this system perspective, heat delivery to a Swedish $\mathrm{DH}$ system would reduce global $\mathrm{CO}_{2}$ emissions in all cases studied, expect when the heat is exported to a large Swedish DH system based on bio-CHP and the marginal user of wood fuel is a producer of FT diesel and build-margin electricity (in this case CCP) is assumed (EMS1). In this case, the available wood fuel would be used to produce FT diesel for the transport sector, substituting fossil diesel. Moreover, the excess heat delivery would reduce electricity production in bio-CHP plants in the same way as described for the system with unlimited biomass resources. The reduced fossil $\mathrm{CO}_{2}$ emissions as a result of more biofuels in the transport sector could not compensate for the emissions derived from increased marginal electricity production in CCP plants. When assuming the Swedish electricity mix, excess heat delivery would always be advantageous regardless of the perspective on biomass.

From a resource perspective, it would be advantageous to use the industrial excess in DH systems. However, it is important to first improve total in-house energy efficiency within the industry and to investigate options for to reusing heat generated in the industrial processes internally. Otherwise, DH co-operations could be a barrier to future investments in energy efficiency measures within the industry, as the measures may reduce the amount of heat suitable for DH delivery.

EMS-2 and EMS-3 have the same marginal user of biomass, but different marginal electricity technologies. Therefore, it is obvious that the only results that differ between these two EMSs are the cases where build-margin electricity is applied in the calculations. Table 3 shows how different perspectives on electricity and biomass use affect the result when analysing a fuel switch at the steel plant. In addition, the consequences of global $\mathrm{CO}_{2}$ emissions are shown for exporting industrial excess heat to DH systems. 
Table 3. Effects on global $\mathrm{CO}_{2}$ emissions when substituting LPG with bio-SNG in reheating furnaces at a scrap-based steel plant. The consequences of exporting excess heat from the biorefinery to a DH system are shown separately. The blue arrows represent EMS with CCP plants as marginal user of wood fuel and the red arrows correspond to alternative use of wood fuel as feedstock for production of biofuel to the transport sector. *No EMS in this study has the combination NGCC as build-margin electricity technology and FT diesel production as marginal user of wood fuel.

\begin{tabular}{lccc}
\hline & $\begin{array}{l}\text { Fuel switch from } \\
\text { LPG to bio-SNG }\end{array}$ & $\begin{array}{l}\text { Excess heat to small } \\
\text { DH system (HOB) }\end{array}$ & $\begin{array}{c}\text { Excess heat to large } \\
\text { DH system (CHP) }\end{array}$ \\
\hline $\begin{array}{l}\text { No restrictions on wood } \\
\text { fuel availability }\end{array}$ & & & $\downarrow$ \\
\hline El: Swedish mix & $\downarrow$ & $\downarrow$ & $\uparrow$ \\
El: European mix & $\downarrow$ & $\downarrow$ & $\uparrow$ \\
El: Build-margin CCP & $\downarrow$ & $\downarrow$ & $\uparrow$ \\
El: Build-margin NGCC & $\downarrow$ & $\downarrow$ & \\
\hline Considering alternative & & & $\downarrow \downarrow$ \\
use of wood fuel & $\uparrow l$ Swedish mix & $\uparrow \downarrow$ & $\downarrow \downarrow$ \\
El: European mix & $\uparrow \downarrow$ & $\downarrow \downarrow$ & $\downarrow \uparrow$ \\
El: Build-margin CCP & $\uparrow \downarrow$ & $\downarrow \downarrow$ & $\downarrow *$ \\
El: Build-margin NGCC & $\uparrow *$ & $\downarrow *$ & \\
\end{tabular}

In this study, a harmonised European bioenergy market is assumed with a conformed wood fuel price. It is of course a simplification to assume that the market for all wood fuel would be without restrictions. High transportation costs may result in more local and regional markets for low-grade wood fuel, because transportation over long distances would not be profitable. Moreover, national policy instruments affect the actors' willingness to pay for bioenergy and hence the wood fuel price could vary between countries as could the marginal user. The type of wood fuel is of relevance for the life-cycle greenhouse gas (GHG) emissions. According to Jäppinen et al. (2014), harvesting residues produce lower emissions than small-diameter energy wood, while stumps produce the most GHG emissions. This was explained by lower production-chain emissions and faster natural decay for harvesting residues.

It is hard to predict the potential marginal user of wood fuel. High-volume users of wood fuel, which could be potential marginal users, could also be a large CHP plant or an iron ore-based steel plant which use charcoal instead of fossil coke and coal in the blast furnace. In this paper, FT diesel was assumed to be the forest-based biofuel of significance in the transport sector. However, there are several other potential biofuels which could be produced from woody biomass. Hasegawa et al. (2010) compared biomethanol and bioethanol and concluded that, from a short-term perspective, bioethanol would reduce $\mathrm{CO}_{2}$ emissions more, while from a long-term perspective biomethanol had greater potential for $\mathrm{CO}_{2}$ mitigation. 
In this study, the best solution would be to apply a perspective which considers build-margin electricity production and alternative use of wood fuel. Two reasons for this are that (1) largescale production of bio-SNG through gasification is not yet a commercialised technology and (2) a gasification plant is an investment with a long economic lifetime. Hence, the investment is a future strategic investment.

\section{Conclusions}

In conclusion, system boundaries should be defined in accordance with the objective of the study. The gasification technology, as well as many other biorefinery concepts, can be introduced on a large scale and has a service life with a relatively long-term perspective, which means that future system perspectives are necessary to give decision-makers useful input for strategic decisions. It is challenging to predict the future energy system, which emphasises the value of studying several different EMSs in order to obtain a robust analysis. Considering biomass as a limited resource, wood fuel utilisation should be prioritised in the following order: (1) in CCP plants; (2) to be converted to bio-SNG and substituted for LPG in steel industry reheating furnaces; and (3) to be converted to FT diesel and replace fossil fuels in the transport sector.

\section{Acknowledgements}

The author would like to thank the personnel at the steel plant for valuable information. The work has been carried out under the auspices of the Energy Systems programme which is financed by the Swedish Energy Agency. The work was co-financed by Göranssonska Fonden.

\section{References}

AISI (2015). American iron and steel institute. www.steel.org/en/Making\%20Steel/Research\%20and\%20Development.aspx. Accessed 6 May 2015.

Axelsson, E., \& Harvey, S. (2010). Scenarios for assessing profitability and carbon balances of energy investments in industry - Pathways to sustainable European energy systems. Gothenburg: AGS, The alliance for global sustainability.

Axelsson, E., Harvey, S., \& Berntsson, T. (2009). A tool for creating energy market scenarios for evaluation of investments in energy intensive industry. Energy, 34(12), 2069-2074.

Basu, P. (2010). Chapter 6 - Design of Biomass Gasifiers. In P. Basu (Ed.), Biomass Gasification and Pyrolysis: Practical Design and Theory. Academic Press.

Broekhoff, D., McCormick, M., Murtishaw, S., Diamant, A., Cowan, J., Platts, J., et al. (2007). The Greenhouse Gas Protocol - Guidelines for Quantifying GHG Reductions from Grid-Connected Electricity Projects. In D. Broekhoff (Ed.): World Resources Institute.

Chalmers Energy Centre (2007). Biokombi Rya biomass gasification project - Final report [Biokombi Rya - Slutrapport från ingående delprojekt]. Gothenburg: Chalmers University of Technology [in Swedish]. 
Cherubini, F. (2010). GHG balances of bioenergy systems - Overview of key steps in the production chain and methodological concerns. Renewable Energy, 35(7), 1565-1573.

Dotzauer, E. (2010). Greenhouse gas emissions from power generation and consumption in a nordic perspective. Energy Policy, 38(2), 701-704.

EEE (2016). Biomass power plant Güssing - Fluidised steam gasification (Thermal Gasification). www.eeeinfo.net/cms/netautor/napro4/appl/na_professional/parse.php?mlay_id=2500\&mdoc_i $\mathrm{d}=1000558$. Accessed 12 January 2016.

European Environment Agency (2009). $\mathrm{CO}_{2}$ (g) per kWh (electricity only).

Gode, J., Martinsson, F., Hagberg, L., Öman, A., Höglund, J., \& Palm, D. (2011). Miljöfaktaboken 2011 - Estimated emission factors for fuels, electricity, heat and transport in Sweden Report No. 1183, Värmeforsk (In Swedish).

Gustavsson, L., Haus, S., Ortiz, C. A., Sathre, R., \& Truong, N. L. (2015). Climate effects of bioenergy from forest residues in comparison to fossil energy. Applied Energy, 138, 36-50.

Göteborg Energi (2016). GoBiGas. gobigas.goteborgenergi.se/English_version/Start. Accessed 12 January 2016.

Hasegawa, F., Yokoyama, S., \& Imou, K. (2010). Methanol or ethanol produced from woody biomass: Which is more advantageous? Bioresource Technology, 101(1, Supplement), S109-S111.

Hawkes, A. D. (2010). Estimating marginal CO2 emissions rates for national electricity systems. Energy Policy, 38(10), 5977-5987.

Hawkes, A. D. (2014). Long-run marginal CO2 emissions factors in national electricity systems. Applied Energy, 125, 197-205.

IEA (2013a). Energy Technology Perspectives: Scenarios \& Strategies to 2050, Fact Sheet Industry. www.iea.org/publications/freepublications/publication/industry.pdf. Accessed 18 November 2013.

IEA (2013b). World Energy Outlook 2013.

JISF (2011). Japan iron and steel federation. www.jisf.or.jp/course50/outline/index_en.html Accessed 6 May 2015.

Jäppinen, E., Korpinen, O.-J., Laitila, J., \& Ranta, T. (2014). Greenhouse gas emissions of forest bioenergy supply and utilization in Finland. Renewable and Sustainable Energy Reviews, 29(0), 369-382.

Levihn, F. (2014). CO2 emissions accounting: Whether, how, and when different allocation methods should be used. Energy, 68.

Lindeström, L., Löfblad, G., \& Löfblad, E. (2008). Environmental impact assessment report with regard to increased production at SSAB Luleå [Miljökonsekvensbeskrivning gällande ökad produktion vid SSAB Luleå]. Svensk MKB and Profu. (In Swedish)

POSCO (2015). Climate Change Policy. www.posco.co.kr/homepage/docs/eng2/html/sustain/environ/s91d1050150c.jsp. Accessed 6 May 2015.

Swedish Energy Agency (2014). Energy in Sweden - Facts and figures.

ULCOS (2015). www.ulcos.org. Accessed 6 May 2015. 
World Steel Association (2014). Crude steel production. www.worldsteel.org/statistics/crudesteel-production.html. Accessed 7 February 2014.

Åbyhammar, T., \& Östergård, K. (2001). Mapping the energy use and energy efficiency potential at Sandvik Steel AB, Sandviken [Kartläggning av energianvändning och energieffektiviseringspotential vid Sandvik Steel AB, Sandviken]. Vattenfall AB. 

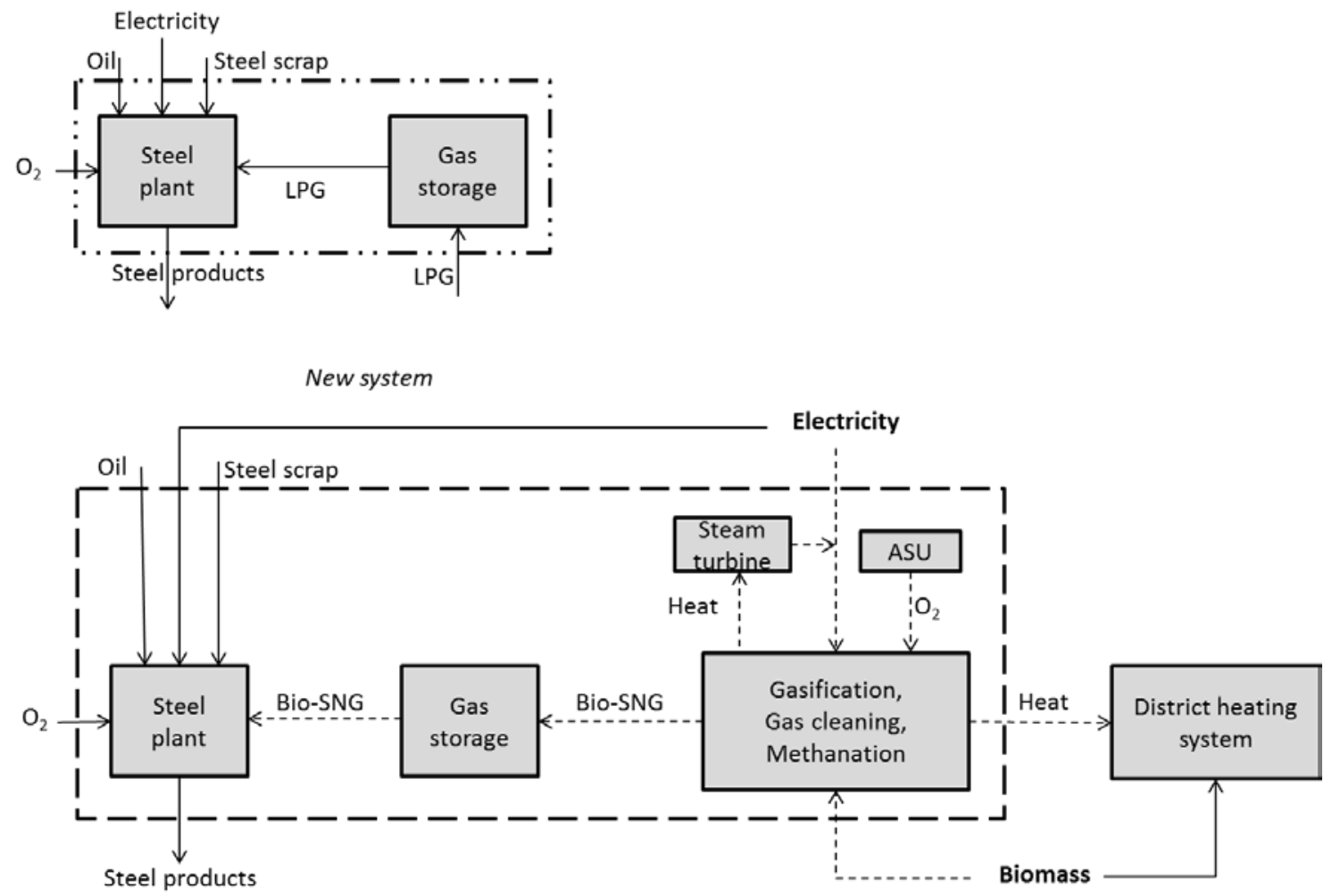

Figure 3. The system studied. The original system is shown at the top and the new system at the bottom. Dotted arrows show the new energy flows introduced when a biomass gasification and methanation system produces fuel for the steel plant. The gasifier's oxygen demand is supplied by an air separation unit (ASU) and electricity is produced from heat from the gas cooling system. 


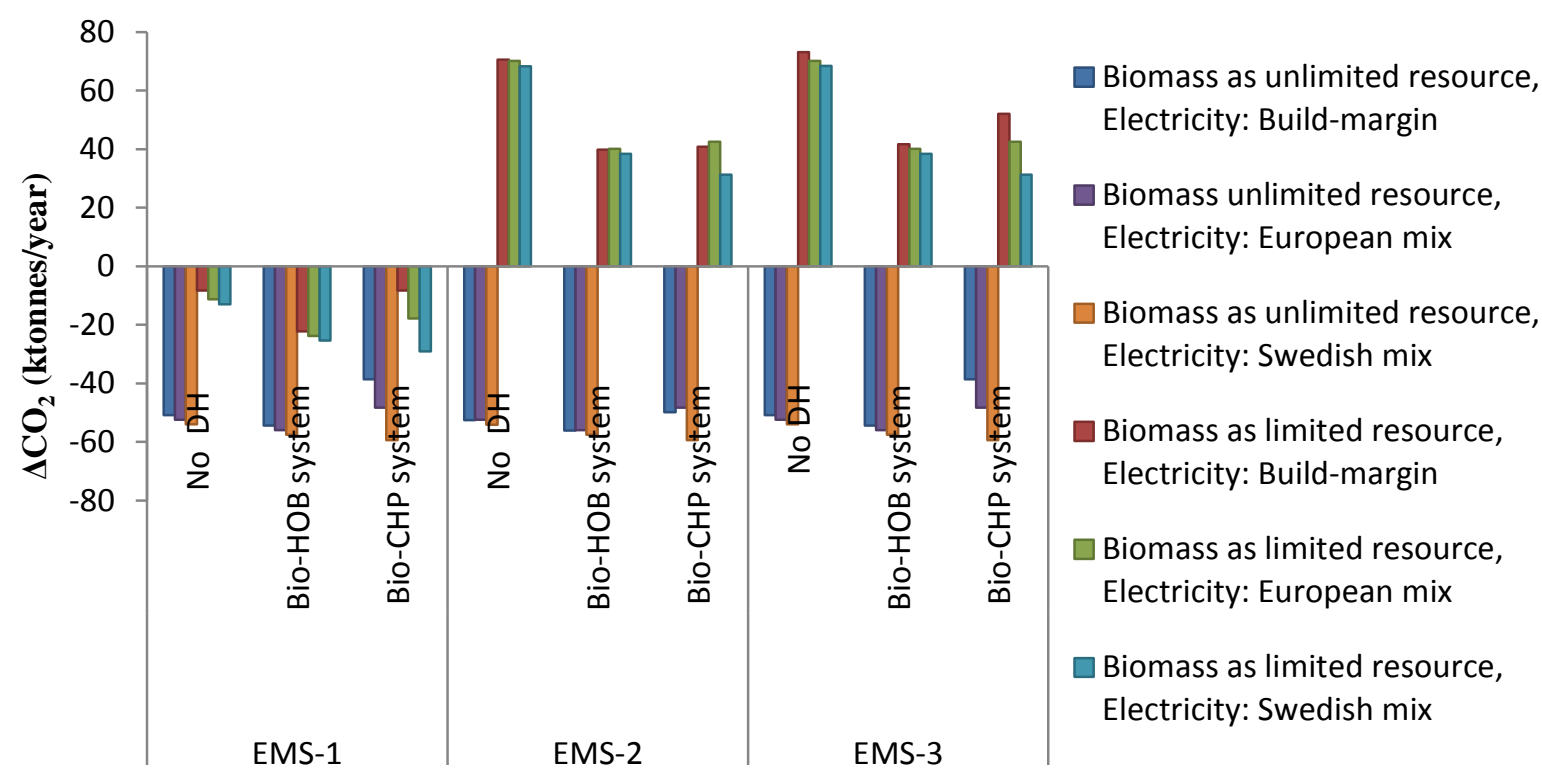

Figure 4. Effects on global $\mathrm{CO}_{2}$ emissions if a scrap-based steel plant in Sweden substitutes 220 GWh LPG per year with bio-SNG as fuel in reheating furnaces. Negative values correspond to reduced emissions. 
Table 1. Performance data for the gasification and methanation system analysed. The capacity of the gasification system is $45 \mathrm{MW}_{\text {th }}$ and it operates at $43 \mathrm{MW}_{\text {th. }}$. The system includes a circulating fluidized bed gasifier, a gas cleaning system, a methanation reactor, an air separation unit (ASU) and a steam turbine. Data was based on (Chalmers Energy Centre 2007).

\begin{tabular}{|c|c|c|c|c|c|c|}
\hline $\begin{array}{l}\text { Biomass input } \\
\left(\mathrm{MW}_{\mathrm{th}}\right)\end{array}$ & $\begin{array}{l}\text { SNG output } \\
\left(\mathrm{MW}_{\text {bio-SNG }}\right)\end{array}$ & Electricity $\left(\mathrm{MW}_{\mathrm{e}}\right)$ & & $\begin{array}{l}\text { DH production } \\
\left(\mathrm{MW}_{\text {heat }}\right)\end{array}$ & Efficiency & \\
\hline \multirow[t]{3}{*}{43} & 27.6 & Demand: & 3.2 & 10.2 & SNG: & 0.64 \\
\hline & & Production: & 2.4 & & Electricity: & -0.02 \\
\hline & & Net production: & -0.8 & & DH: & 0.24 \\
\hline
\end{tabular}


Table 2. $\mathrm{CO}_{2}$ emissions factors generated by the ENPAC tool when considering LCA and build-margin electricity. Two perspectives on wood fuel are shown: (1) wood fuel is considered available for all potential users or (2) alternative use of wood fuel is considered. Input to the ENPAC tool was fossil fuel prices and $\mathrm{CO}_{2}$ emissions charges taken from World Energy Outlook (WEO) 2013, which represent the new policies scenario (input to EMS-1) and the $450 \mathrm{ppm}$ scenario (input to EMS-2) (IEA 2013b). In addition, average values of the prices from the scenarios in WEO 2013 were input into a third energy market scenario (EMS-3).

\begin{tabular}{|c|c|c|c|}
\hline Energy market scenario (EMS) & EMS-1 & EMS-2 & EMS-3 \\
\hline Build-margin technology for electricity & $C C P^{a}$ & $N G C C^{b}$ & CCP \\
\hline Marginal user of wood fuel ${ }^{c}$ & $F T^{d}$ & CCP & CCP \\
\hline \multicolumn{4}{|l|}{ Biomass as unlimited resource } \\
\hline LPG (kg CO $\left.2 / \mathrm{MWh}_{\text {fuel }}\right)$ & 245 & 245 & 245 \\
\hline Natural gas ( $\left.\mathrm{kg} \mathrm{CO} / \mathrm{MWh}_{\text {fuel }}\right)$ & 224 & 224 & 224 \\
\hline Biomass ( $\left.\mathrm{kg} \mathrm{CO} / \mathrm{MWh}_{\text {fuel }}\right)$ & 8 & 8 & 8 \\
\hline Electricity $\left(\mathrm{kg} \mathrm{CO}_{2} / \mathrm{MWh}_{\mathrm{e}}\right)$ & 714 & 340 & 714 \\
\hline \multicolumn{4}{|l|}{ District heating ( $\mathrm{kg} \mathrm{CO} / \mathrm{MWh}_{\text {heat }}$ ) } \\
\hline Bio-HOB ${ }^{\mathrm{e}}$ in Sweden & 43 & 43 & 43 \\
\hline Bio-CHP ${ }^{f}$ in Sweden & -148 & -33 & -148 \\
\hline \multicolumn{4}{|l|}{ Biomass as limited resource } \\
\hline LPG (kg CO $\left.2 / \mathrm{MWh}_{\text {fuel }}\right)$ & 245 & 245 & 245 \\
\hline Natural gas ( $\left.\mathrm{kg} \mathrm{CO} 2 / \mathrm{MWh}_{\text {fuel }}\right)$ & 224 & 224 & 224 \\
\hline Biomass (kg CO $\left.2 / \mathrm{MWh}_{\text {fuel }}\right)$ & 119 & 356 & 356 \\
\hline Electricity $\left(\mathrm{kg} \mathrm{CO}_{2} / \mathrm{MWh}_{\mathrm{e}}\right)$ & 714 & 340 & 714 \\
\hline \multicolumn{4}{|l|}{ District heating ( $\mathrm{kg} \mathrm{CO} / \mathrm{MWh}_{\text {heat }}$ ) } \\
\hline Bio-HOB ${ }^{\mathrm{e}}$ in Sweden & 150 & 363 & 363 \\
\hline Bio-CHP ${ }^{f}$ in Sweden & -19 & 351 & 236 \\
\hline
\end{tabular}

${ }^{a}$ Coal condensing power plant, ${ }^{b}$ Natural gas combined cycle, ${ }^{c}$ For the scenarios with limited biomass availability, ${ }^{\mathrm{d}}$ Producer of Fischer Tropsch diesel, e Heat-only-boiler, ${ }^{\mathrm{f}}$ Combined heat and power 
Table 3. Effects on global $\mathrm{CO}_{2}$ emissions when substituting LPG with bio-SNG in reheating furnaces at a scrap-based steel plant. The consequences of exporting excess heat from the biorefinery to a DH system are shown separately. The blue arrows represent EMS with CCP plants as marginal user of wood fuel and the red arrows correspond to alternative use of wood fuel as feedstock for production of biofuel to the transport sector. *No EMS in this study has the combination NGCC as build-margin electricity technology and FT diesel production as marginal user of wood fuel.

$\begin{array}{ll}\text { Fuel switch from Excess heat to Excess heat to large } \\ \text { LPG to bio-SNG } & \begin{array}{l}\text { small DH system } \\ \text { (HOB) }\end{array}\end{array}$

\begin{tabular}{lccc}
\hline No restrictions on & & & \\
wood fuel availability & & $\downarrow$ & $\downarrow$ \\
\hline El: Swedish mix & $\downarrow$ & $\downarrow$ & $\uparrow$ \\
El: European mix & $\downarrow$ & $\downarrow$ & $\uparrow$ \\
El: Build-margin CCP & $\downarrow$ & $\downarrow$ & \\
El: Build-margin & $\downarrow$ & & \\
NGCC & & & $\downarrow \downarrow$ \\
\hline Considering alternative & & $\downarrow \downarrow$ & $\downarrow \downarrow$ \\
use of wood fuel & & $\downarrow \downarrow$ & $\downarrow *$ \\
\hline El: Swedish mix & $\uparrow \downarrow$ & $\downarrow \downarrow$ & \\
El: European mix & $\uparrow \downarrow$ & $\downarrow *$ & \\
El: Build-margin CCP & $\uparrow \downarrow$ & & \\
El: Build-margin & $\uparrow *$ & & \\
NGCC & & & \\
\hline
\end{tabular}

